\title{
Final height in isolated GH deficiency type 1A: effects of 5-year treatment with IGF-I
}

\author{
M F Messina, F De Luca, M Wasniewska, M Valenzise, F Lombardo and L Ghizzoni ${ }^{1}$ \\ Institutes of Pediatrics, Universities of Messina and ${ }^{1}$ Parma, Italy \\ (Correspondence should be addressed to F De Luca, Istituto di Clinica Pediatrica, Policlinico Universitario, 98123 Messina, Italy; \\ Email: fdeluca@unime.it)
}

\begin{abstract}
Data concerning final height $(\mathrm{FH})$ in isolated growth hormone deficiency type 1A (IGHD1A) are scanty and controversial. In this paper we report the FH outcome of two girls with IGHD1A who were treated either with GH only (first patient) or with GH during the first 8 years and successively with IGF-I (second patient). In the first patient, FH was only slightly subnormal and slightly taller with respect to target height (TH). Surprisingly, FH was severely subnormal and very far from TH in the patient who underwent IGF-I therapy for $>5$ years: an auxological outcome similar to the one recently reported in the only two cases in the literature of patients with IGHD1A who have been treated with IGF-I until near FH achievement. We conclude that IGHD1A could have a very heterogeneous phenotypic expression in terms of FH and that IGF-I therapy, even though initiated some years before puberty onset and prolonged for more than 5 years, may not be able to ensure the normalization of height prognosis and the achievement of an $\mathrm{FH}$ close to $\mathrm{TH}$.
\end{abstract}

European Journal of Endocrinology 144 379-383

\section{Introduction}

Isolated growth hormone deficiency type 1A (IGHD1A) is a very rare autosomal recessive disorder resulting from deletions within the GH gene cluster and is characterized by an early and severe clinical picture of GHD in the homozygous children (1-3). Despite the strong initial catch-up growth that follows GH treatment, the prognosis of adult height in these patients has been reported to be severely impaired in most cases $(4,5)$ owing to the appearance of high bindingcapacity anti-GH antibodies under GH treatment with consequent growth arrest (6-9).

More recently, the availability of recombinant insulinlike growth factor-I (IGF-I) may offer the possibility of an effective and physiologically correct mode of treatment in these patients, when the insensitivity to GH develops secondarily to anti-GH antibody formation as a consequence of GH treatment. The first short term data concerning growth velocity under IGF-I therapy in IGHD1A children have been very encouraging (1014 ), but the efficacy of therapy for longer periods of time remains to be established.

The aim of this paper was to report the final height (FH) of a patient with IGHD1A who was treated with IGF-I for $>5$ years, i.e. a sufficiently long period to allow reliable conclusions about the long term efficacy of IGF-I therapy in IGHD1A. The FH of this girl was compared with the one of another patient with IGHD1A who underwent GH therapy only.

Finally, the adult height of the two patients was compared with $\mathrm{FH}$ or near $\mathrm{FH}$ of other cases in the literature who were treated either with GH only $(4,15$, 16 ) or with both GH and IGF-I (17).

\section{Case reports}

The first report concerns an Italian girl with early onset GHD, diagnosed at the age of 3.2 years on the basis of a severe growth retardation, an impressive GHD phenotype and the results of endocrinological investigations that revealed no $\mathrm{GH}$ secretion in response to three pharmacological stimulations (insulin, clonidine and GH-releasing hormone) and low IGF-I serum levels (Table 1).

Restriction endonuclease analysis of genomic DNA demonstrated that the cause of GHD was a large deletion within the human $\mathrm{GH}$ gene cluster of $45 \mathrm{~kb}$. Only one $(6.7 \mathrm{~kb})$ of the six fragments of the $G H$ gene cluster was present, namely that containing the $C S-B$ gene. The other five fragments $(3.8,1.1,2.9,8.3$, $5.3 \mathrm{~kb}$ ) containing the remaining four genes of the $\mathrm{GH}$ gene cluster $(G H-1, G H-2, C S-L, C S-A)$ were deleted. The parents of our patients were heterozygous for the same deletion. Molecular features of this girl and her 
Table 1 Molecular defect and main endocrine features at diagnosis and auxological evolution from birth to final height.

\begin{tabular}{lcc}
\hline & Patient 1 & Patient 2 \\
\hline Molecular defect (kb) & 45 & 3.8 \\
Serum GH peak (ng/ml) & $<0.02$ & Undetectable \\
IGF-I (ng/ml) & $<60$ & 10 \\
Birth & & \\
Length (cm) & 45.0 & 45.0 \\
Weight (g) & 2300 & 2900 \\
Start of GH therapy & & \\
Age (years) & 3.2 & 0.6 \\
Height (SDS) & -7.0 & -5.0 \\
Bone age (years) & 1 & 0.3 \\
Start of IGF-I therapy & & \\
Age (years) & - & -4.6 \\
Height (SDS) & - & 7.2 \\
Bone age (years) & - & \\
Onset of puberty & & -4.0 \\
Age (years) & 9.6 & 10.4 \\
Height (SDS) & -2.0 & 128.6 \\
Bone age (years) & 10.2 & 153.6 \\
Final height (cm) & 153.0 & \\
Target height (cm) & 149.0 & \\
\hline
\end{tabular}

parents have already been reported in detail previously (8).

In this patient substitutive treatment with authentic recombinant GH (Saizen, Serono, Italy) was initiated at 3.2 years and prolonged until growth arrest $(15.2$ years), with a progressive catch-up growth (from -7.0 to -2.0 standard deviation scores (SDS) at the onset of puberty) (Table 1). She maintained a normal growth in the presence of low titer $(1: 100)$ and low binding capacity $(0.22 \mathrm{mg} \mathrm{GH} / \mathrm{l})$ anti-GH antibodies. The FH was only slightly subnormal and taller with respect to target height (TH). Table 1 summarizes the main auxological data of this patient, from birth to $\mathrm{FH}$ achievement, and compares this to the second case.

In this patient only three readings concerning IGF-I serum levels during the entire follow-up were available: at diagnosis (Table 1), on GH therapy during pubertal development $(421 \mathrm{ng} / \mathrm{ml})$ and after treatment withdrawal $(60.7 \mathrm{ng} / \mathrm{ml}$ ) (reference ranges of our laboratory for pre-pubertal and pubertal subjects were $89-250$ and $250-832 \mathrm{ng} / \mathrm{ml}$ respectively).

The second report concerns another Italian girl with subnormal birth length (Table 1) and neonatal hypoglycemia, who was admitted to our hospital at the age of 7 months due to a severe height deficiency $(-5.0$ SDS $)$ and a physical appearance strongly suggestive of congenital GHD. Her plasma GH levels were undetectable in response to three pharmacological stimulation tests (insulin, carbidopa and GH-releasing hormone). On the basis of the restriction endonuclease analysis of genomic DNA she was diagnosed as having IGHD1A. As already described previously (18), she is homozygous for a deletion of the structural gene for GH-N. She is lacking a $3.8 \mathrm{~kb}$ hybridizing BamHI fragment. The parents and sister of the patient were carriers of the same deletion and, in fact, in all of them the large $26 \mathrm{~kb}$ HindIII fragment is replaced by an $18.5 \mathrm{~kb}$ fragment (18).

The initiation of biosynthetic GH therapy (methionyl GH; Somatonorm, Kabi Vitrum, Sweden) in the first 2 years and successively authentic recombinant $\mathrm{GH}$ (Genotropin, Kabi Vitrum) was followed over the next 4 years by an excellent catch-up growth (from -5.0 to -1.4 SDS) and no anti-GH antibody development.

High titer (1:50 000) and high binding-capacity $(0.54 \mathrm{mg} \mathrm{GH} / \mathrm{l})$ anti-GH antibodies were detected for the first time after the first 4 years of GH treatment (at the age of 4.6) in the serum of this girl. Their development was followed by a severe catch-down growth of $7.3 \mathrm{~cm} / 4$ years (19).

Owing to the persistence of the antibodies and the consequent growth arrest, this patient stopped GH therapy at the age of 8.6 years and was then treated with IGF-I (rhIGF-I, Pharmacia and Upjohn, Stockholm, Sweden) at an initial dose of $40 \mu \mathrm{g} / \mathrm{kg}$ twice daily. This dose was increased to $80 \mu \mathrm{g} / \mathrm{kg}$ twice daily after 2 years and then to $120 \mu \mathrm{g} / \mathrm{kg}$ twice daily from the onset of puberty and over the following 2.3 years. IGF-I treatment was withdrawn at the age of 13.9 years. The $\mathrm{FH}$ was achieved at the age of 15.0 years, but this was severely subnormal and significantly lower with respect to TH (Table 1). Pre-pubertal height gain during IGF-I therapy was $15.1 \mathrm{~cm} / 3$ years, whereas pubertal height gain over the following 2.3 years was only $6.1 \mathrm{~cm}$. The total height gain during the entire IGF-I treatment period was $21.2 \mathrm{~cm} / 5.3$ years. Table 1 summarizes the auxological evolution and outcome of this patient and compares this with that of the first case.

The onset of IGF-I therapy was associated with significant increase of IGF-I serum levels (from 22 to $117 \mathrm{ng} / \mathrm{ml}$ ) which, however, remained below the lowest limit of the above reported reference range during the overall IGF-I therapy period despite the high doses used.

\section{Methods}

Supine lengths and standing heights were measured with a supine measuring table and a wall-mounted stadiometer (Harpenden and Holtain Ltd, Crymmych, UK). The TH was calculated by [(father's height + mother's height $+/-13)$ : 2] (20). SDS for length, height and TH were calculated on the basis of the data of Tanner \& Whitehouse (21).

Serum GH and IGF-I concentrations were measured by RIA using commercially available kits (Biodata, Milan, Italy). Bone age was estimated according to the method of Greulich and Pyle (22).

Sera from both of our patients were examined for the presence of anti-GH antibodies by an RIA method at the 
Analytical Department, Kabi Vitrum AB, Stockholm, Sweden (23). This method determined the binding of radiolabeled hGH to serum. The antibody titer represents the highest plasma dilution binding $50 \%$ of $\mathrm{GH}$ tracer in a serial dilution experiment and was determined as described previously (7). The binding capacity was computed from a Scatchard plot of bound and free concentrations of hGH. This was obtained by performing the assay at a dilution corresponding to approximately $40 \%$ binding in the presence of a fixed amount of $\left[{ }^{125} \mathrm{I}\right] \mathrm{hGH}$ and twofold increasing concentrations of unlabelled hGH ranging between 3 and $200 \mathrm{mIU} / \mathrm{l}$. The binding capacity is expressed as $\mathrm{mg} / \mathrm{l}$.

\section{Restriction endonuclease analyses}

Aliquots of high molecular weight nuclear DNA isolated from peripheral blood samples obtained from family members were digested with appropriate restriction endonucleases under conditions specified by the suppliers. The DNA fragments were then transferred to nitrocellulose membranes and hybridized with a GH-1 cDNA probe (3) or a $1.1 \mathrm{~kb}$ EcoRI-Sst I-derived genomic fragment that lies downstream of GH-1 (1). The filters were washed and autoradiographed as described previously (3).

IGF-I treatment in our second case was authorized by the Ethical Committee of Messina University Hospital and written informed consent was given by the parents of the patient.

\section{Discussion}

The two patients with IGHD1A reported in this paper exhibited a very different FH outcome, that is, normal in one case but severely subnormal in the second. Such important differences in the outcome of adult stature as observed in these girls confirm the significant phenotypic heterogeneity of this disease, already demonstrated even in siblings with the same genotype $(4,8)$.

Our two patients showed a great heterogeneity also with respect to antibodies' formation, especially from the quantitative point of view; in fact, the titer of antibodies was very low in the first case and very high in the second girl. The different immunological response may be responsible for the different long term growth response to GH therapy. This different pattern in the two patients does not seem to be conditioned by the magnitude of gene defect, considering that a large mutational deletion is present in the first case, whereas only a small portion of DNA is missing in the second one.

A great phenotypic heterogeneity with respect to the production of antibodies has been well documented in the literature $(6,9,15,16,24)$ and has also been shown in siblings with an identical genotypic expression $(4,8)$. Thus, the immune response to exogenous $\mathrm{GH}$ is not related exclusively to the size of the gene deletion but can be secondary to other gene products as well as the human-leucocyte-antigen molecules (25).

Both of our patients exhibited a sub-normal birth length, an auxological finding that has been reported in other series of patients with early onset GHD (26-28), thus suggesting a crucial role of $\mathrm{GH}$ in fetal growth (26).

Birth size has been reported to be extremely heterogeneous in patients with IGHD1A and not to correlate with the deletion size (8). This is in accordance with the present report, as the birth length of our patients was identical whereas the amplitude of GH-N gene deletion was very different.

Until some years ago no advantageous therapeutic alternatives were available when patients with $\mathrm{GH}$ gene deletions started developing anti-GH antibodies that progressively attenuated the positive effects of $\mathrm{GH}$ therapy on growth velocity. In the last decade, the availability of a recombinant human IGF-I has provided a physiologically correct therapeutic opportunity for children with either IGHD1A or GH insensitivity syndrome, two disorders distinct from the pathogenetic point of view but very similar from the auxologic and clinical point of view. IGF-I has been used for short periods in both these diseases, proving to be effective in promoting short term height acceleration (10-14, 2931).

Whether IGF-I holds the potential to normalize adult height in patients with IGHD1A, however, remains an open question. At present, in fact, the few available data concerning $\mathrm{FH}$ or near $\mathrm{FH}$ in IGF-I-treated subjects with GH gene deletions are very disappointing. Our patient (No 2 in Table 1), despite a very prolonged period of IGF-I treatment (64 months) achieved a very short adult height. Moreover, after an initial acceptable growth response to IGF-I therapy, she exhibited an evident height deceleration, with a very disappointing pubertal growth spurt. To summarize, no overall catchup growth was recorded in this case during the entire period of IGF-I therapy.

In a recent multicenter study on long term treatment with IGF-I, the whole series included 31 patients with GH insensitivity syndrome and only two subjects with $G H$ gene deletion $(11,17)$. Both of these patients, after treatment with IGF for 33-37 months, attained a near FH taller than that recorded at the onset of IGF-I therapy but significantly shorter compared with TH and absolutely sub-normal, an auxological outcome very similar to that observed in our IGF-I-treated patient.

In summary, although IGF-I replacement can be assumed to be a physiological approach to treatment in IGHD1A after anti-GH antibody formation, its long term results in terms of adult height cannot be considered sufficiently satisfactory. Also, in our IGF-Itreated patient, as well as in both cases reported by Ranke et al. (17), FH was found to be severely subnormal and very far from TH. Because the experience with IGF-I therapy in patients with IGHD1A is still so 
limited, it cannot be excluded that the doses of IGF-I and/or the treatment modalities used in these cases have not been optimal.

The disappointing pubertal height spurt that followed the first growth response to IGF-I therapy in our case is difficult to explain and has not been observed hitherto in other IGF-I-treated subjects (17). Nevertheless, only a few patients with either IGHD1A or GH insensitivity syndrome have been treated until nearepiphyseal closure, which does not allow definitive conclusions on the extent of pubertal growth during IGF-I treatment (17).

To conclude, our case reports, as well as the analysis of the data in the literature concerning the ultimate height of the patients with IGHD1A, suggest that FH in patients with IGHD1A may be extremely short, slightly sub-normal or low normal, that this phenotypic heterogeneity may be conditioned by differences existing in the production of anti-GH antibodies, and that IGF-I therapy, even though initiated some years before the onset of puberty and prolonged for $>5$ years, might not ensure the normalization of height prognosis and the achievement of a FH close to $\mathrm{TH}$ or at least in the normal range.

\section{Acknowledgements}

This work was partly supported by Pharmacia and Upjohn, Stockholm, Sweden.

\section{References}

1 Vnencak-Jones CL, Phillips JA III, Chen EY \& Seeburg PH. Molecular basis of human growth hormone gene deletions. PNAS 198885 5615-5619.

2 Phillips JA III, Hjelle BL, Seeburg PH \& Zachmann M. Molecular basis for familial isolated growth hormone deficiency. PNAS 198178 6372-6375.

3 Goossens M, Brauner R, Czernichow P, Duquesnoy P \& Rappaport R. Isolated growth hormone $(\mathrm{GH})$ deficiency type $1 \mathrm{~A}$ associated with a double deletion in the human GH gene cluster. Journal of Clinical Endocrinology and Metabolism $1986 \mathbf{6 2}$ $712-716$.

4 Rivarola MA, Phillips JA III, Migeon CJ, Heinrich JJ \& Hjelle BJ. Phenotypic heterogeneity in familial isolated growth hormone deficiency type 1A. Journal of Clinical Endocrinology and Metabolism 198459 34-40.

5 Phillips JA III, Ferrandez A, Frish H, Illig R \& Zuppinger K. Defects of growth hormone genes. Clinical syndromes. In Human Growth Hormone, pp 211-226. Eds S Raiti \& RA Tolman. New York and London: Plenum Press, 1986.

6 Schwarz S, Berger P, Frish H, Moncayo R, Phillips JA III \& Wick G. Growth hormone blocking antibodies in a patient with deletion of the GH-N gene. Clinical Endocrinology 198727 213-224.

7 Illig R. Growth hormone antibodies in patients treated with different preparations of human growth hormone (hGH). Journal of Clinical Endocrinology 197031 679-688.

8 Ghizzoni L, Duquesnoy P, Torresani T, Vottero A, Goossens M \& Bernasconi S. Isolated growth hormone deficiency type $1 \mathrm{~A}$ associated with a 45-kilobase gene deletion within the human growth hormone gene cluster in an Italian family. Pediatric Research 199436 654-659.
9 Illig R, Prader A, Ferrandez A \& Zachmann M. Hereditary prenatal growth hormone deficiency with increased tendency to growth hormone antibody formation. Acta Paediatrica Scandinavica 197160607.

10 Youlton R. Growth hormone gene deletion: results of treatment with recombinant human insulin-like growth factor I. Acta Paediatrica 1994399 150-151.

11 Ranke MB, Savage MO, Chatelain PG, Preece MA, Rosenfeld RG, Blum WF et al. Insulin-like growth factor I improves height in growth hormone insensitivity: two years' results. Hormone Research 199544 253-264.

12 Arnhold IJ, Oliveira SB, Osorio MG \& Mendoca BB. Insulin-like growth factor-I treatment in two children with growth hormone gene deletions. Journal of Pediatric Endocrinology and Metabolism $199912499-506$.

13 Nishi Y, Hamamoto K, Kajiyama M, Fujiwara M, Miyagawa S, Hasegawa $\mathrm{Y}$ et al. Treatment of isolated growth hormone deficiency type $1 \mathrm{~A}$ due to $\mathrm{GH}$-gene deletion with recombinant human insulin-like growth factor-I. Acta Paediatrica $1993 \mathbf{8 2}$ 983-986.

14 Underwood LE, Backeljauw P, Duncan V and GHIS Collaborative Group. Effects of insulin-like growth factor-I treatment on statural growth, body composition and phenotype of children with growth hormone insensitivity syndrome. Acta Paediatrica 1999428 182-184.

15 Braga S, Phillips JA III, Joss E, Scwharz H \& Zuppinger K. A new type of familial growth hormone deficiency due to a $8.5 \mathrm{~kb}$ deletion within the growth hormone gene cluster. In Endocrine Genetics and Genetics of Growth, pp 103-111. Eds J Papadatos \& CS Bartsocas. New York: Alan R Liss, 1985.

16 Nishi Y, Masuda H, Nishimura S, Kihara M, Suwa S, Tachibana K et al. Isolated growth hormone deficiency due to the hGH-I gene deletion with (type 1A) and without (the Israeli-type) hGH antibody formation during hGH therapy. Acta Endocrinologica 1990122 267-271.

17 Ranke MB, Savage MO, Chatelain PG, Preece MA, Rosenfeld RG \& Wilton P. Long term treatment of growth hormone insensitivity syndrome with IGF-I. Results of the European multicentre study - the working group on growth hormone insensitivity syndromes. Hormone Research 199951 128-134.

18 De Luca F, Duquesnoy P, Arrigo T, Lombardo F \& Goossens M. Long-lasting catch-up growth under bio-methionyl growth hormone treatment in an infant with isolated growth hormone deficiency type 1A. Acta Paediatrica Scandinavica $1991801235-$ 1240.

19 De Luca F, Duquesnoy P, Arrigo T, Lombardo F \& Goossens M. Very late immune response to growth hormone (GH) therapy in an infant with GH-N gene deletion. Acta Paediatrica Scandinavica 199281730.

20 Tanner JM, Goldstein H \& Whitehouse RH. Standards for children's height at age 2 to 9 years allowing for height of parents. Archives of Disease in Childhood 197045 755-762.

21 Tanner JM \& Whitehouse RH. Clinical longitudinal standards for height, weight, height velocity, weight velocity and the stages of puberty. Archives of Disease in Childhood 197651 170-179.

22 Greulich WW \& Pyle SI. Radiographic atlas of skeletal development of the hand and wrist. Standford: University Press, 1959.

23 Method of analysis A 405: determination of antibodies to somatotropin by radioimmunoassay (RIA). Stockholm: Kabi Vitrum AB, 1986

24 Laron Z, Kelijman M, Pertzelan A, Keret R, Shoffner JM \& Parks JS. Human growth hormone gene deletion without antibodies formation or growth arrest during treatment: a new disease entity? Israel Journal of Medical Sciences 198521 9991006.

25 Andersson R. Immunological aspects of human growth hormone. Acta Paediatrica Scandinavica 1986325 48-54.

26 Gluckman PD, Gunn AJ, Wray A, Cutfield WS, Chatelain PG, Guilbaud $\mathrm{O}$ et al. Congenital idiopathic growth hormone deficiency associated with prenatal and early post-natal growth 
failure. The International Board of the Kabi Pharmacia International Growth Study. Journal of Pediatrics 1992121 920-923.

27 Laron Z \& Pertzelan A. Somatotrophin in antenatal and perinatal growth and development. Lancet 19697596 680-681.

28 De Luca F, Bernasconi S, Blandino A, Cavallo L \& Cisternino M. Auxological, clinical and neuroradiological findings in infants with early onset growth hormone deficiency. Acta Paediatrica 199584 561-565.

29 Hintz RL. Current and potential uses of growth hormone and insulin-like growth factor-I. North American Journal of Clinical Endocrinology and Metabolism 199625 759-773.

30 Azcona C, Preece MA, Rose SJ, Fraser N, Rappaport R, Ranke MB et al. Growth response to rhIGF-I $80 \mathrm{mcg} / \mathrm{kg}$ twice daily in children with growth hormone insensitivity syndrome: relationship to severity of clinical phenotype. Journal of Clinical Endocrinology and Metabolism 199951 787-792.

31 Laron Z, Anin S, Klipper Aurbach Y, Klinger B, Effects of insulinlike growth factor on linear growth, head circumference and body fat in patients with Laron-type dwarfism. Lancet 1992339 1258-1261.

Received 6 June 2000

Accepted 27 November 2000 